\title{
Spring and summer contrast in new particle formation over nine forest areas in North America
}

\author{
F. Yu ${ }^{1}$, G. Luo ${ }^{1}$, S. C. Pryor ${ }^{2}$, P. R. Pillai ${ }^{3}$, S. H. Lee ${ }^{4}$, J. Ortega ${ }^{5}$, J. J. Schwab ${ }^{1}$, A. G. Hallar ${ }^{6}$, W. R. Leaitch ${ }^{7}$, \\ V. P. Aneja ${ }^{3}$, J. N. Smith ${ }^{5,8}$, J. T. Walker ${ }^{3,9}$, O. Hogrefe ${ }^{1, \text { a }}$, and K. L. Demerjian ${ }^{1}$ \\ ${ }^{1}$ Atmospheric Sciences Research Center, State University of New York, 251 Fuller Road, Albany, NY 12203, USA \\ ${ }^{2}$ Department of Earth and Atmospheric Sciences, Cornell University, Ithaca, NY 14853, USA \\ ${ }^{3}$ Department of Marine, Earth, and Atmospheric Sciences, North Carolina State University, Raleigh, NC 27695, USA \\ ${ }^{4}$ College of Public Health, Kent State University, Kent, OH, USA \\ ${ }^{5}$ National Center for Atmospheric Research, P.O. Box 3000, Boulder, CO 80307, USA \\ ${ }^{6}$ Desert Research Institute, Storm Peak Laboratory, Steamboat Springs, CO 80488, USA \\ ${ }^{7}$ Environment Canada, Science and Technology Branch, Toronto, ON, Canada \\ ${ }^{8}$ Applied Physics Dept., University of Eastern Finland, P.O. Box 1627, Kuopio 70211, Finland \\ ${ }^{9}$ US Environmental Protection Agency, Office of Research and Development, Durham, NC 27711, USA \\ ${ }^{a}$ currently at: Durham Technical Community College, Durham, NC 27703, USA
}

Correspondence to: F. Yu (fyu@albany.edu)

Received: 19 June 2015 - Published in Atmos. Chem. Phys. Discuss.: 6 August 2015

Revised: 24 November 2015 - Accepted: 24 November 2015 - Published: 18 December 2015

\begin{abstract}
Recent laboratory chamber studies indicate a significant role for highly oxidized low-volatility organics in new particle formation (NPF), but the actual role of these highly oxidized low-volatility organics in atmospheric NPF remains uncertain. Here, particle size distributions (PSDs) measured in nine forest areas in North America are used to characterize the occurrence and intensity of NPF and to evaluate model simulations using an empirical formulation in which formation rate is a function of the concentrations of sulfuric acid and low-volatility organics from alpha-pinene oxidation (Nucl-Org), and using an ion-mediated nucleation mechanism (excluding organics) (Nucl-IMN). On average, NPF occurred on $\sim 70 \%$ of days during March for the four forest sites with springtime PSD measurements, while NPF occurred on only $\sim 10 \%$ of days in July for all nine forest sites. Both Nucl-Org and Nucl-IMN schemes capture the observed high frequency of NPF in spring, but the Nucl-Org scheme significantly overpredicts while the NuclIMN scheme slightly underpredicts NPF and particle number concentrations in summer. Statistical analyses of observed and simulated ultrafine particle number concentrations and frequency of NPF events indicate that the scheme without organics agrees better overall with observations. The two
\end{abstract}

schemes predict quite different nucleation rates (including their spatial patterns), concentrations of cloud condensation nuclei, and aerosol first indirect radiative forcing in North America, highlighting the need to reduce NPF uncertainties in regional and global earth system models.

\section{Introduction}

Particle number concentration is an important factor in the health and climate impacts of atmospheric aerosols. High number concentrations of ultrafine particles may lead to adverse health effects (Knibbs et al., 2011). As cloud condensation nuclei $(\mathrm{CCN})$, atmospheric particles modify cloud properties and precipitation and thus affect the hydrological cycle and climate indirectly. Aerosol indirect radiative forcing (IRF) remains a major uncertainty in assessing climate change (IPCC, 2013; Carslaw et al., 2013). Secondary particles formed via nucleation dominate the global total particle number abundance (Spracklen et al., 2008; Pierce and Adams, 2009; Yu and Luo, 2009), and global simulations indicate that the aerosol IRF is quite sensitive to nucleation parameterizations (Wang and Penner, 2009; Kazil et al., 2010; 
Yu et al., 2012). Furthermore, as a result of its dependence on meteorological conditions, emissions, and chemistry, new particle formation (NPF) is an important physical process involved in a number of climate feedback loops. Laboratory experiments indicate that sulfuric acid, ammonia, amines, ions, and certain organic compounds and oxidants can all contribute to NPF. But there are numerous chemical reactions and physical processes involved, so there is no single unified theory that accurately describes NPF, and the levels of enhancements due to different species vary widely among various studies (e.g., Zhang et al., 2004; Erupe et al., 2011; Chen et al., 2012; Dawson et al., 2012; Almeida et al., 2013; Berndt et al., 2014; Riccobono et al., 2014; Glasoe et al., 2015).

The indication that nucleation is significantly enhanced by organic species formed via oxidation of biogenic volatile organic compounds (VOCs) (e.g., Riccobono et al., 2014) is of interest as it may have important implications for the interactions of anthropogenic and biogenic emissions and the associated climate forcing. Nevertheless, the various roles of organics and their oxidation products in NPF in the real atmosphere remains an active research area. Particle size distributions (PSDs) have been measured in a variety of environments around the globe, and many of these measurements have been used to study NPF events (e.g., Kulmala et al., 2004). To evaluate the potential role of oxidation products of biogenic VOCs in NPF, PSDs taken over forested areas are particularly useful. In the present study, we analyze NPF events and non-events based on PSDs measured over nine forest areas in North America (NA) and compare them to model simulations including and not including organics in the nucleation rate calculation. Since biogenic VOC emissions and their oxidation are strongest in the summer, we use the observed spring and summer contrast in NPF events to study the possible role of organics in NPF in NA and evaluate our current understanding of NPF processes in the atmosphere.

\section{Methods}

\subsection{Measurements}

PSDs from $\sim 3-10 \mathrm{~nm}$ to $>\sim 100 \mathrm{~nm}$ have been widely used to identify and to study particle nucleation and growth events in the atmosphere (e.g., Kulmala et al., 2004). In this study, we focus on PSDs observed in various years in eight US forest sites and one southern Canadian forest site, summarized in Table 1. The locations of these sites are marked on a Google map (http://maps.google.com) in Fig. 1. Egbert (EGB) is surrounded by a mixture of forests and farmland which is subject to a strong biogenic influence under certain conditions (Slowik et al., 2010; Pierce et al., 2014), while all other eight sites are directly located in forest or mountain areas. PSDs have been measured at these nine sites with scan-
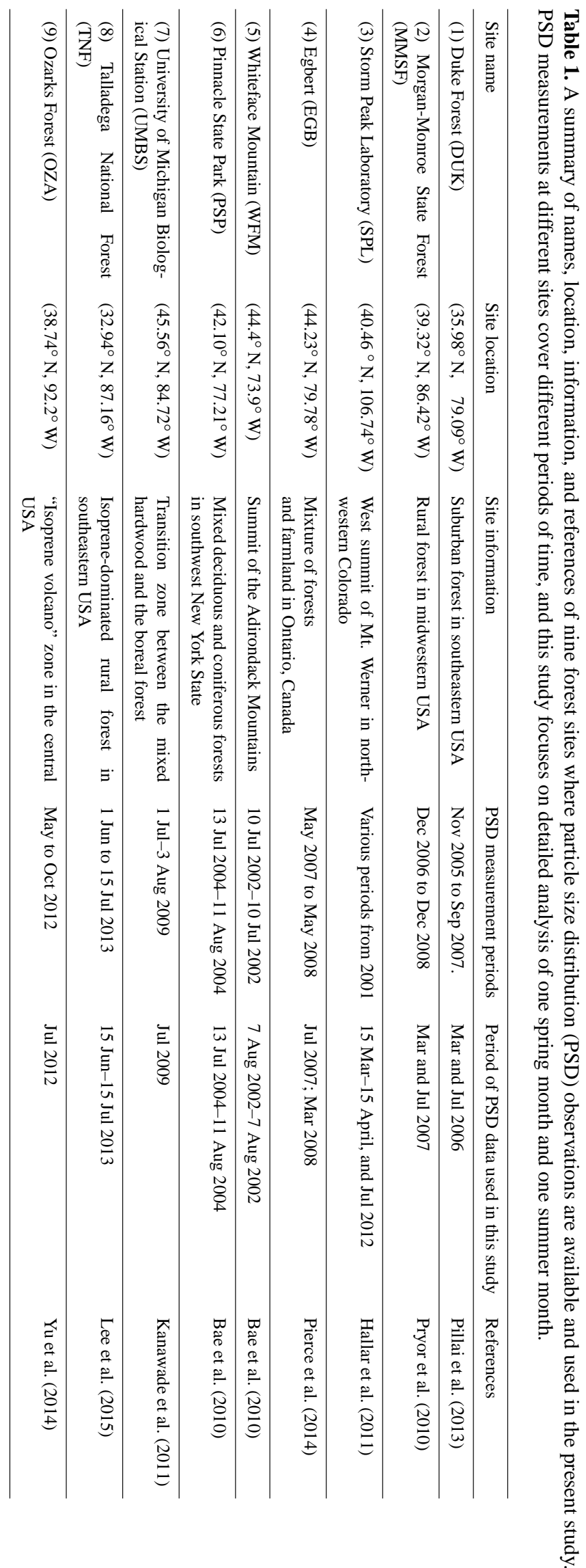
ning mobility particle sizers (SMPSs) during different time periods. Sites 1-4 have at least 1 year of continuous PSD data, while sites 5-9 have PSD data only during the summer (for different years). PSDs for one spring and one summer month for sites 1-4 and for one summer month for sites 5-9 are given in Fig. 1. It is clear that nucleation in the spring is much more frequent and stronger (i.e., higher concentrations of nucleation mode particles) when compared to summer months. Detailed analysis of these data and comparisons with simulations are given in the Results section.

\subsection{Model and simulations}

The modeling work in this study is based on the GEOSChem model (e.g., Bey et al., 2001) with an advanced particle microphysics (APM) model incorporated (Yu and Luo, 2009). GEOS-Chem is a global 3-D model of atmospheric composition driven by assimilated meteorological observations from the Goddard Earth Observing System (GEOS) of the NASA Global Modeling and Assimilation Office (GMAO). The model has been developed and used by many research groups and contains a number of state-of-the-art modules treating various chemical and aerosol processes (e.g., Bey et al., 2001; Chung and Seinfeld, 2002; Martin et al., 2003; Park et al., 2004; Evans and Jacob, 2005; Liao et al., 2007; Henze et al., 2008). The APM module in GEOSChem is optimized to simulate the formation of secondary particles and their growth to $\mathrm{CCN}$ sizes, using high size resolution (30 bins) for particles in the dry size range of 1.2$120 \mathrm{~nm}$ diameter. There are an additional 10 bins for 0.12 $12 \mu \mathrm{m}$ particles (Yu and Luo, 2009). More detailed information about GEOS-Chem and updates can be found at the model website (http://geos-chem.org/).

To study the possible role of organics in NPF, we employ the organics-mediated nucleation parameterization (NuclOrg) derived from a CLOUD (Cosmics Leaving OUtdoor Droplets) chamber study as given in Riccobono et al. (2014),

$J_{1.7}=k_{m} \times\left[\mathrm{H}_{2} \mathrm{SO}_{4}\right]^{2} \times[\mathrm{BioOxOrg}]$,

where $J_{1.7}$ is the formation rate $\left(\# \mathrm{~cm}^{-3} \mathrm{~s}^{-1}\right)$ of particles of $\sim 1.7 \mathrm{~nm} ; k_{m}$ is the fitting pre-factor with a value of $3.27 \times 10^{-21} \mathrm{~cm}^{6} \mathrm{~s}^{-1}$ (90\% confidence interval: $1.73 \times 10^{-21}$ to $\left.6.15 \times 10^{-21} \mathrm{~cm}^{6} \mathrm{~s}^{-1}\right)$; and $\left[\mathrm{H}_{2} \mathrm{SO}_{4}\right]$ and [BioOxOrg] are the gas-phase concentrations $\left(\# \mathrm{~cm}^{-3}\right)$ of $\mathrm{H}_{2} \mathrm{SO}_{4}$ and biogenic oxidized organic (BioOxOrg) vapors, respectively. In the chamber study reported in Riccobono et al. (2014), BioOxOrg molecules are organic compounds of relatively low volatility from the oxidation of pinanediol (a first-generation oxidation product of $\alpha$-pinene) and represent later-generation oxidation products of biogenic monoterpenes.

In GEOS-Chem v8-03-02, on which this study is based, reactive VOCs are grouped into six categories $\left(\mathrm{VOC}_{i}, i=1-\right.$ 6 ), with $\mathrm{VOC}_{1}=\alpha$-pinene $+\beta$-pinene + sabinene $+\Delta-3$ carene + terpenoid ketones; $\mathrm{VOC}_{2}=$ limonene; $\mathrm{VOC}_{3}=\alpha$ - terpinene $+\gamma$-terpinene + terpinolene; $\mathrm{VOC}_{4}=$ myrcene + terpenoid alcohols + ocimene; $\mathrm{VOC}_{5}=$ sesquiterpenes; and $\mathrm{VOC}_{6}=$ isoprene. $\mathrm{Yu}$ (2011) extended the two-product secondary organic aerosol (SOA) formation model (Chung and Seinfeld, 2002) to predict concentrations of extremely low-volatile secondary organic gas ([LV-SOG]) from successive oxidation aging of the first-generation oxidation products of various VOCs, i.e., semivolatile SOG (SV-SOG) and medium-volatile SOG (MV-SOG). The extended SOA formation scheme substantially increases the simulated SOA mass concentrations and improves the agreement of model predictions with aerosol mass spectrometer (AMS) SOA measurements (Yu, 2011). LV-SOG has a saturation vapor concentration in the range of $\sim 0.0001-0.03 \mu \mathrm{g} \mathrm{m}^{-3}$, corresponding to the extremely low-volatility SOG reported in Ehn et al. (2014). The production rate of LV-SOG depends on the saturation vapor concentrations of MV-SOG and SVSOG and temperature (Yu, 2011).

To use Eq. (1) to calculate organics-mediated nucleation, we separate LV-SOG from the oxidation products of $\mathrm{VOC}_{1}$ (named $\mathrm{LV}_{-} \mathrm{SOG}_{\alpha \text {-pinene }}$ thereafter) from those associated

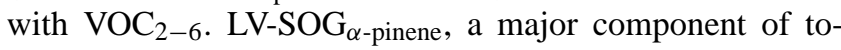
tal LV-SOG, corresponds well to the BioOxOrg reported in the chamber study of Riccobono et al. (2014). For comparison, simulations based on the ion-mediated nucleation of the $\mathrm{H}_{2} \mathrm{SO}_{4}-\mathrm{H}_{2} \mathrm{O}$ binary system (Nucl-IMN) (Yu, 2010) are also presented. Nucleation rates based on the NuclOrg scheme depend on $\left[\mathrm{H}_{2} \mathrm{SO}_{4}\right]$ and [ $\left.\mathrm{LV}-\mathrm{SOG}_{\alpha \text {-pinene }}\right]$ only, while those based on the Nucl-IMN scheme depend nonlinearly on $\left[\mathrm{H}_{2} \mathrm{SO}_{4}\right]$, temperature $(T)$, relative humidity $(\mathrm{RH})$, ionization rate, and surface area of pre-existing particles ( $\mathrm{Yu}$, 2010). Based on the CLOUD chamber study (Almeida et al., 2013; Riccobono et al., 2014), IMN is significant or dominant when $J_{1.7}$ is below $\sim 1 \mathrm{~cm}^{-3} \mathrm{~s}^{-1}$, but neutral nucleation takes over when $J_{1.7}>\sim 1 \mathrm{~cm}^{-3} \mathrm{~s}^{-1}$. Nucl-IMN calculates formation rates of particles at wet sizes of $\sim 1.5 \mathrm{~nm}$. The nucleated particles are added into the first bin (wet size $\sim 1.5 \mathrm{~nm}$ ) of the secondary particles, and the processes to grow them to large sizes considered in GEOS-Chem/APM include kinetic condensation of $\mathrm{H}_{2} \mathrm{SO}_{4}$ and total LV-SOG, equilibrium uptake of nitrate and ammonium, partitioning uptake of SV-SOG and MV-SOG, and self-coagulation (Yu, 2011).

The horizontal resolution of GEOS-Chem employed for this study is $2^{\circ} \times 2.5^{\circ}$, and there are 47 vertical layers (with 14 layers from surface to $\sim 2 \mathrm{~km}$ above the surface). The emission inventories and schemes used can be found at the GEOS-Chem website and have also been summarized in Yu and Hallar (2014). Biogenic VOC emissions from terrestrial vegetation are based on the Model of Emissions of Gases and Aerosols from Nature (MEGAN) (Guenther et al., 2006), which computes emissions for plant functional types as a function of temperature, solar radiation, leaf area index (LAI), and leaf age. MEGAN does not consider the effect of 

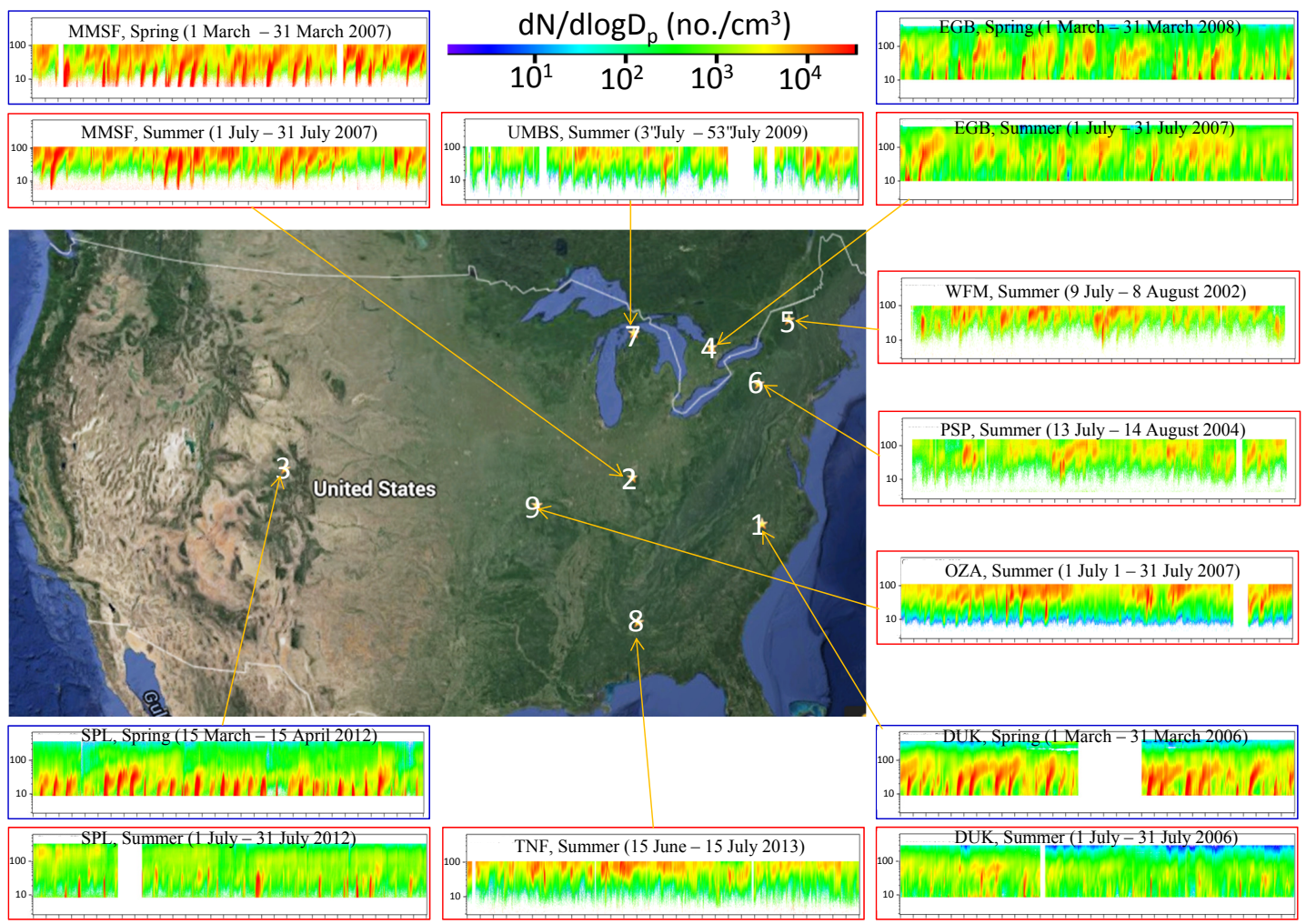

Figure 1. The locations of nine measurement sites in the forest areas in North America (see Table 1 for the names and references of the sites). Also shown are the particle size distributions measured in one spring month at sites 1-4 (with blue frames) and one summer month at all sites (with red frames).

water stress (drought), which may suppress biogenic emissions (Pryor et al., 2014).

This study focuses on the NA region, and values of all tracers and relevant parameters in all layers over the nine forest sites marked in Fig. 1 were output at each chemistry time step (30 min) for detailed analysis and comparison with measurements. Since PSD measurements at different sites were taken in different years, multiple-year simulations have been carried out and comparisons are for the same month/year for any given site. Since GEOS-Chem was driven by assimilated meteorology, the key meteorology fields are generally consistent with observations at sites of comparisons (e.g., Yu and Hallar, 2014).

\subsection{NPF events and non-events}

To assess the ability of different nucleation schemes to capture NPF events (or non-events) at various sites, an objective criterion is needed to decide from the evolution of PSDs whether a given day is an event day or not. An NPF event has generally been defined as the appearance of a clear new nucleation mode $(<\sim 25 \mathrm{~nm})$ for a significant period of time (hours) accompanied by the growth of the mode diameter during its existence (e.g., Dal Maso et al., 2005). Similar to the method used in Hallar et al. (2011) and Venzac et al. (2008), in this study an NPF event is defined if the $\mathrm{d} N / \operatorname{d} \log D_{\mathrm{p}}$ value (where $\mathrm{d} N$ is the number concentration of particles within diameter range $\mathrm{d} D_{\mathrm{p}}$ ) averaged within three bins near $10 \mathrm{~nm}$ maintains a level of $3000 \mathrm{~cm}^{-3}$ or higher continuously for more than $2 \mathrm{~h}$, and the mode diameter grows during the period. The growth rate of the nucleation mode was calculated by linearly fitting the change of mode diameters (Lehtinen and Kulmala, 2003). To simplify the comparison, all days with measurements available but not defined as NPF event days are counted as non-event days.

\section{Results}

VOC emissions in the summer are known to be much higher than VOC emissions in the spring. The high VOC emissions coupled with strong photochemistry and oxidation lead to significantly higher production rates and concentrations of oxidized SOGs of varied volatilities (medium volatility, semivolatile, and low volatility) in the summer. Both [LV$\mathrm{SOG}]$ and $\left[\mathrm{LV}-\mathrm{SOG}_{\alpha \text {-pinene }}\right]$ in the summer are much higher (by a factor of $\sim 4-10$ ) than those in the spring, while $\left[\mathrm{H}_{2} \mathrm{SO}_{4}\right]$ has a similar concentration in the spring as in the summer (not shown). Figure 2 shows horizontal distributions of monthly mean nucleation rates $(J)$ in the boundary 

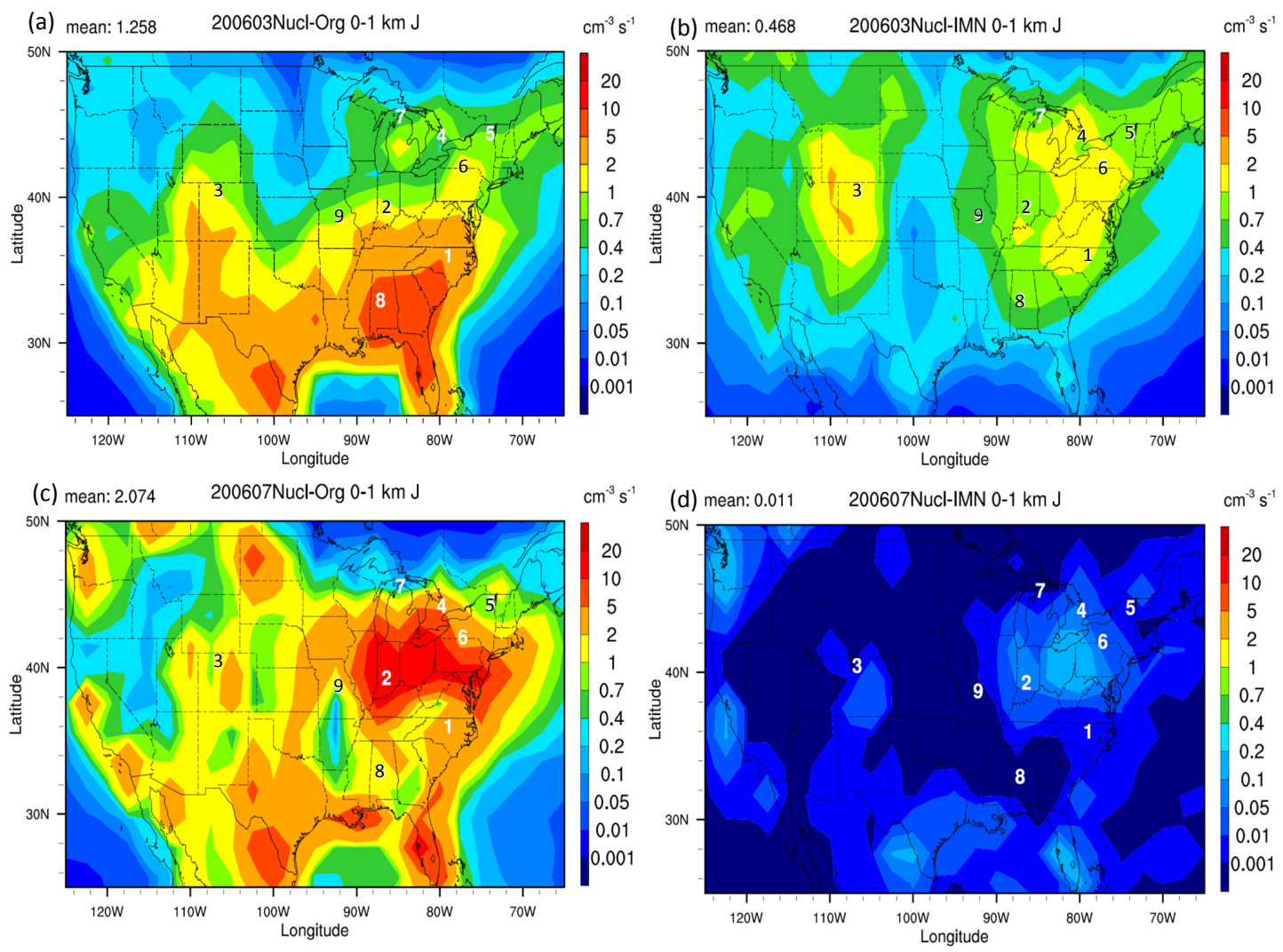

Figure 2. Horizontal distributions of monthly mean nucleation rates $(J)$ in the boundary layer $(0-1 \mathrm{~km}$ above surface) in March (a, b) and July (c, d) of 2006 based on two different nucleation schemes, i.e., Nucl-Org (a, c) and Nucl-IMN (b, d) (see text for details). The locations of sites 1-9 (Table 1) are marked.

layer (0-1 km above the surface) in March and July of 2006 based on two different nucleation schemes (i.e., Nucl-Org and Nucl-IMN). The two nucleation schemes clearly predict significantly different spatial patterns and seasonal variations of nucleation rates. In March, $J_{\text {Nucl-Org }}$ is highest in the southeastern USA as a result of high $\left[\mathrm{LV}-\mathrm{SOG}_{\alpha \text {-pinene }}\right]$ in the region, reaching $5-10 \mathrm{~cm}^{-3} \mathrm{~s}^{-1}$ (Fig. 2a), while $J_{\text {IMN }}$ has two separate eastern and western nucleation zones, with monthly mean $J$ up to $\sim 1-2 \mathrm{~cm}^{-3} \mathrm{~s}^{-1}$ (Fig. 2b). In July, boundary layer $J_{\text {Nucl-Org }}$ (Fig. 2c) is 2 orders of magnitude higher than $J_{\text {IMN }}$ (Fig. 2d), although both indicate a high nucleation center in the northeastern USA surrounding the Ohio valley, with other scattered high nucleation zones in the southern and western USA along the coast. The low $J_{\text {IMN }}$ is due to the high temperature in the summer. The shift of the high $J_{\text {Nucl-Org }}$ nucleation zone from southeastern in March to northeastern in July is mainly associated with the change in the spatial distributions of [LV-SOG $\alpha$-pinene].

Comparisons of model predictions with in situ measurements are critical to evaluate our current understanding of atmospheric nucleation processes and to identify areas requiring further research. The PSDs measured at the nine forest sites, as marked in Figs. 1-2, provide a reasonably represen- tative data set for this purpose. As shown in Fig. 1, all the PSDs have lower cut-off sizes of $10 \mathrm{~nm}$ or smaller, with some as small as $3-5 \mathrm{~nm}$. Due to wall losses and lower charging and counting efficiencies of small particles, PSDs for mobility diameters smaller than $\sim 10 \mathrm{~nm}$ may have large uncertainties. The nano-SMPSs generally have upper cutoff sizes of $\sim 100 \mathrm{~nm}$. The GEOS-Chem-APM model simulates PSDs from $\sim 1.5 \mathrm{~nm}$ to larger than $10 \mu \mathrm{m}$. Figure 3 gives an example of the comparison between observed and simulated PSDs during two 10-day periods in March and July of 2006 in Duke Forest, along with time series of the concentration of condensation nuclei $(\mathrm{CN})$ between 10 and $100 \mathrm{~nm}\left(\mathrm{CN}_{10-100}\right.$, integrated from PSDs). Similar plots for one spring month and one summer month for sites 1-4 and one summer month for sites 5-9 are given in Figs. S1-S9 in the Supplement. The diurnal profile of $\mathrm{CN}_{10-100}$ is a good indication of new particle formation and growth. Statistical analyses of observed and simulated $\mathrm{CN}_{10-100}$ for all sites are presented later in this section.

To assess the ability of different nucleation schemes to capture NPF events (or non-events) at various sites, we use the criterion described in Sect. 2.3 to decide from the evolution of PSDs whether a given day is an event day or not. To 
(a) Observed PSDs, DUK, 19-28 March 2006

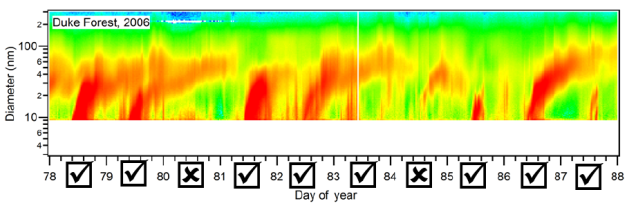

(c) Simulated PSDs based on Nucl-Org, DUK, 19-28 March 2006

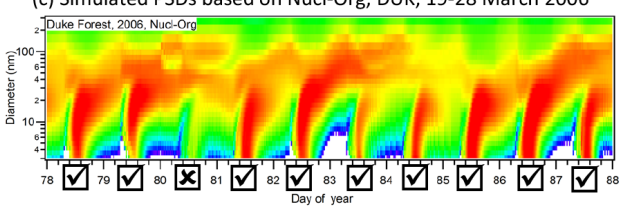

(e) Simulated PSDs based on Nucl-IMN, DUK, 19-28 March 2006
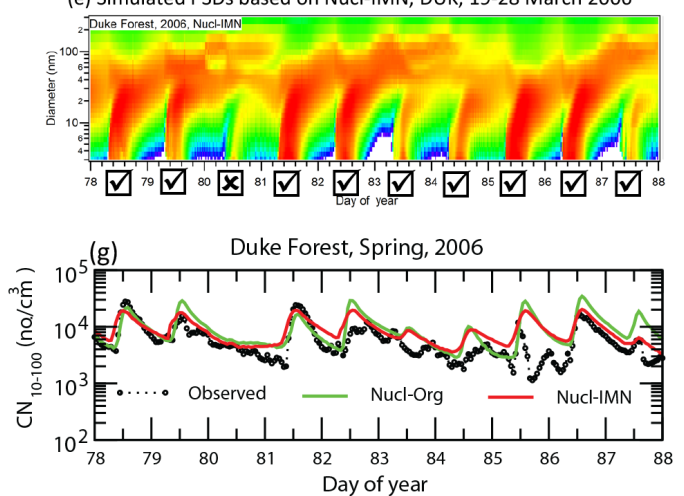

(b) Observed PSDs, DUK, 11-20 July 2006
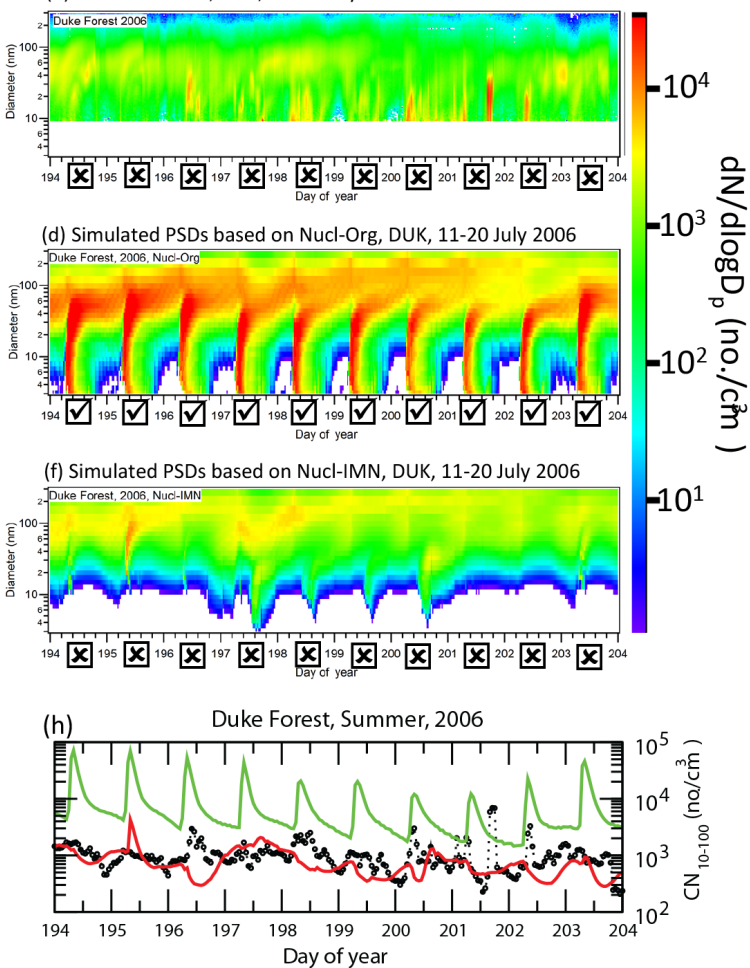

Figure 3. Particle size distributions (PSDs) observed $(\mathbf{a}, \mathbf{b})$ and simulated based on Nucl-Org $(\mathbf{c}, \mathbf{d})$ and Nucl-IMN (e, f) schemes during two 10-day periods in March (a, $, \mathbf{e}, \mathbf{e})$ and July $(\mathbf{b}, \mathbf{d}, \mathbf{f})$ of 2006 in Duke Forest (DUK), along with time series of the concentration of condensation nuclei between 10 and $100 \mathrm{~nm}\left(\mathrm{CN}_{10-100}\right)(\mathbf{g}, \mathbf{h})$. The event $(\checkmark)$ and non-event $(\times)$ days determined based on the criterion given in Sect. 2.3 for the observed and simulated PSDs are marked in (a-f).

illustrate this decision process, we mark the event $(\checkmark)$ and non-event $(x)$ days determined based on this criterion for the observed and simulated PSDs in Fig. 3. For the 10-day period in March, this criterion gives 8, 9, and 9 event days for the observed NPF in Duke Forest (Fig. 3a), simulated with Nucl-Org (Fig. 3c) and simulated with Nucl-IMN (Fig. 3e), respectively. For the 10-day period in July, the corresponding numbers of event days are 0,10 , and 0 . The requirement for the $\mathrm{d} N / \operatorname{dlog} D_{\mathrm{p}}$ at $D_{\mathrm{p}}=\sim 10 \mathrm{~nm}$ of $3000 \mathrm{~cm}^{-3}$ or higher is to filter out weak NPFs such as the one on day 80 of observed and simulated PSD (Fig. 3a, c, e) and day 84 of observed PSD (Fig. 3d). The $2 \mathrm{~h}$ duration requirement is intended to filter out the short and sharp spikes likely as a result of local plumes rather than regional nucleation, such as the one appearing on days 201 and 202 of the observation. Our visual inspection indicates that this criterion captures most of major observed and simulated NPFs. While this criterion is not perfect, it enables us to evaluate objectively the ability of different nucleation schemes to capture NPF events (or non-events) at various sites during long observation periods. A slight change in this criterion (for example, increasing $\mathrm{d} N / \operatorname{d} \log D_{\mathrm{p}}$ at $D_{\mathrm{p}}=10 \mathrm{~nm}$ from 3000 to $5000 \mathrm{~cm}^{-3}$, or the duration from 2 to $3 \mathrm{~h}$ ) does not impact the main conclusions of this study.
It is clear from Fig. 3a-b that NPF events observed in Duke Forest are much more frequent and concentrations of nucleation mode particles are much higher in the spring than in the summer. More frequent and stronger observed NPF events in the spring have been reported in many previous field measurement studies (e.g., Dal Maso et al., 2005; Pryor et al., 2010; Kanawade et al., 2011; Pillai et al., 2013; Pierce et al., 2014). Both schemes predict frequent NPF events in March (Fig. 3c, e), which is consistent with observations, although the Nucl-Org scheme generally gives stronger NPF events and higher $\mathrm{CN}_{10-100}$ (Fig. 3g). Model simulations based on the Nucl-Org scheme (Eq. 1) suggest that frequent (almost daily, Fig. 3d) and stronger NPF (Fig. 3h) should occur in the summer in Duke Forest, which was not observed with measurements (Fig. 3b). The relatively less frequent or lack of events in the summer indicates that, at least, LV$\mathrm{SOG}_{\alpha \text {-pinene }}$ cannot be the dominant nucleation factor as [LV-

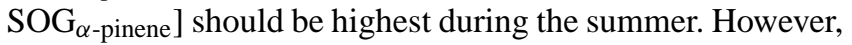
the Nucl-IMN scheme is consistent with the observed lack of nucleation in the summer in Duke Forest. Note that there is no explicit temperature dependence in Eq. (1), an issue that is discussed later.

Figure 4 presents a statistical analysis and comparison of simulated NPF event days and $\mathrm{CN}_{10-100}$ based on two nu- 
Table 2. Observed and simulated fraction (or frequency) of nucleation event days $\left(F_{\text {nucl }}\right)$ and $\mathrm{CN}_{10-100}$, for one spring month (sites $1-$ 4 average) and one summer month (sites 1-9 average). The Pearson correlation coefficient $(r)$ of simulated and observed time series of $\mathrm{CN}_{10-100}$ as well as proportion correct (PC) of days.

\begin{tabular}{|c|c|c|c|c|c|c|c|c|}
\hline & \multicolumn{4}{|c|}{ Spring (4 sites) } & \multicolumn{4}{|c|}{ Summer (9 sites) } \\
\hline & $F_{\text {nucl }}$ & $\mathrm{CN}_{10-100}$ & $r$ & $\mathrm{PC}$ & $F_{\text {nucl }}$ & $\mathrm{CN}_{10-100}$ & $r$ & PC \\
\hline Observation & 0.69 & 5441 & & & 0.08 & 2450 & & \\
\hline Nucl-Org & 0.76 & 7606 & 0.37 & 0.68 & 0.60 & 6385 & 0.16 & 0.43 \\
\hline Nucl-IMN & 0.76 & 6198 & 0.49 & 0.63 & 0.07 & 1783 & 0.22 & 0.88 \\
\hline
\end{tabular}
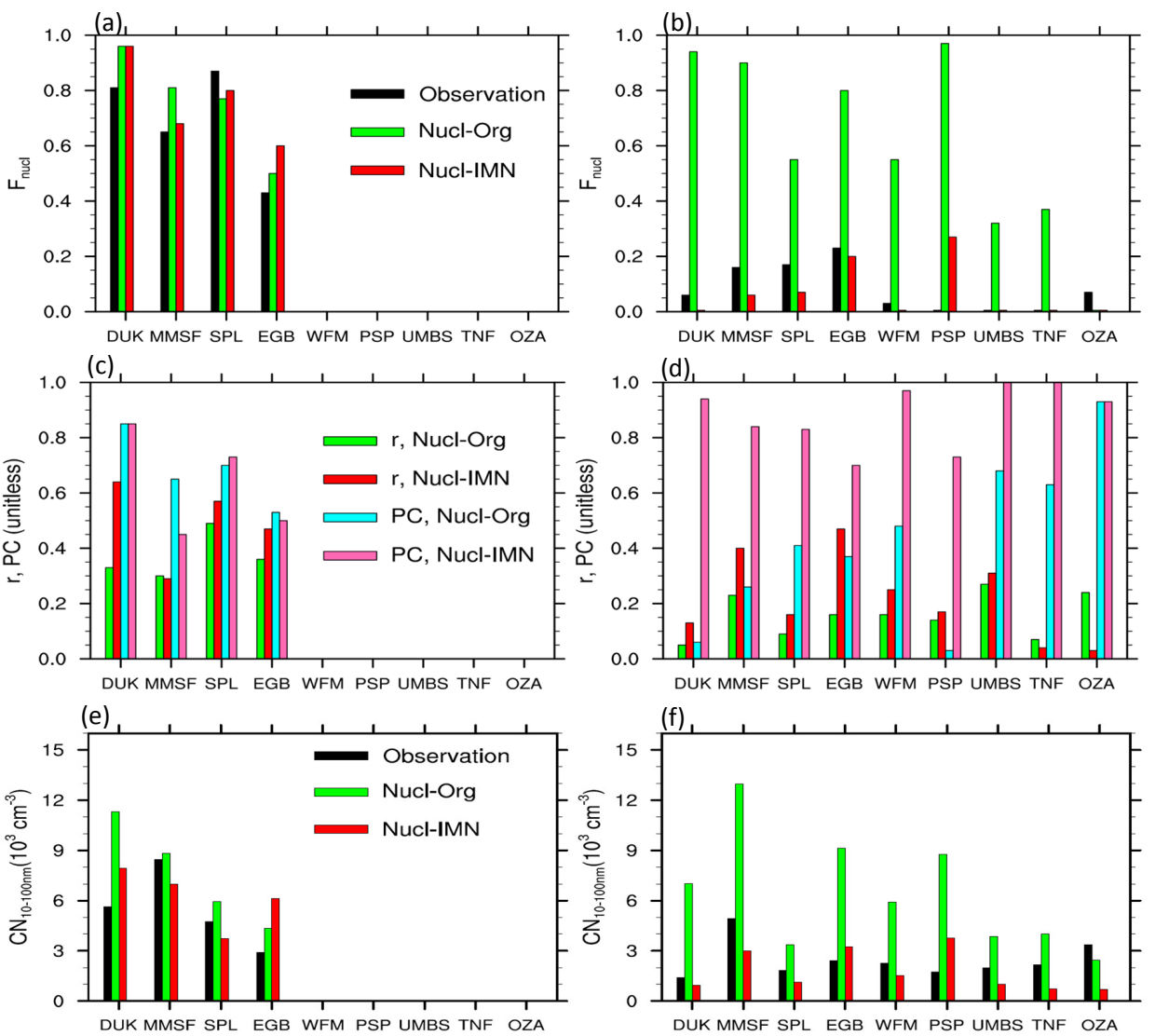

Figure 4. Statistical analysis of simulated NPF events and $\mathrm{CN}_{10-100}$ based on two nucleation schemes (Nucl-Org, Nucl-IMN) and comparison with observations at four forest sites for the spring month (a, c, e) and nine sites for the summer month $(\mathbf{b}, \mathbf{d}, \mathbf{f})$. $F_{\text {nucl }}$ is the fraction (or frequency) of nucleation event days (a, b). The proportion correct (PC) (c, $\mathbf{d}$ ) is defined as (\# of modeled events that were events $+\#$ of modeled non-events that were non-events)/(total \# of modeled events + total \# of modeled non-events). Monthly mean $\mathrm{CN}_{10-100}(\mathbf{e}, \mathbf{f})$ and correlation coefficient $(r)(\mathbf{c}, \mathbf{d})$ of hourly mean $\mathrm{CN}_{10-100}$ during the month are also given.

cleation schemes with observations at four forest sites for the spring month and for all nine sites for the summer month. Table 2 gives the averaged values. For the statistical analysis, we look into the fraction (or frequency) of nucleation event days $\left(F_{\text {nucl }}\right)$ (Fig. $4 \mathrm{a}-$ spring; Fig. $4 \mathrm{~b}-$ summer), the proportion correct (PC) (Fig. 4c-d), Pearson correlation coefficient $(r)$ of the observed and simulated scatterplots of $\mathrm{CN}_{10-100}$ (Fig. 4c-d), and monthly mean $\mathrm{CN}_{10-100}$ (Fig. 4e-f). For the four sites with PSD data in the spring, NPF events oc- curred on $81,65,87$, and $43 \%$ of days for sites DUK, MMSF, SPL, and EGB, respectively (Fig. 4a), with an average value of $69 \%$. Both nucleation schemes capture most of the NPF events in the spring month (four-site average of $76 \%$ for both Nucl-Org and Nucl-IMN). In July, there are no obvious NPF events for sites 1, 5-9 (DUK, WFM, PSP, UMBS, TNF, OZA) and infrequent events $(\sim 20 \%)$ for sites $2-4$ (MMSF, SPL, EGB). Nucl-Org significantly overpredicts the nucleation frequency (by up to $\sim 50-97 \%$ ) for sites 1 and 

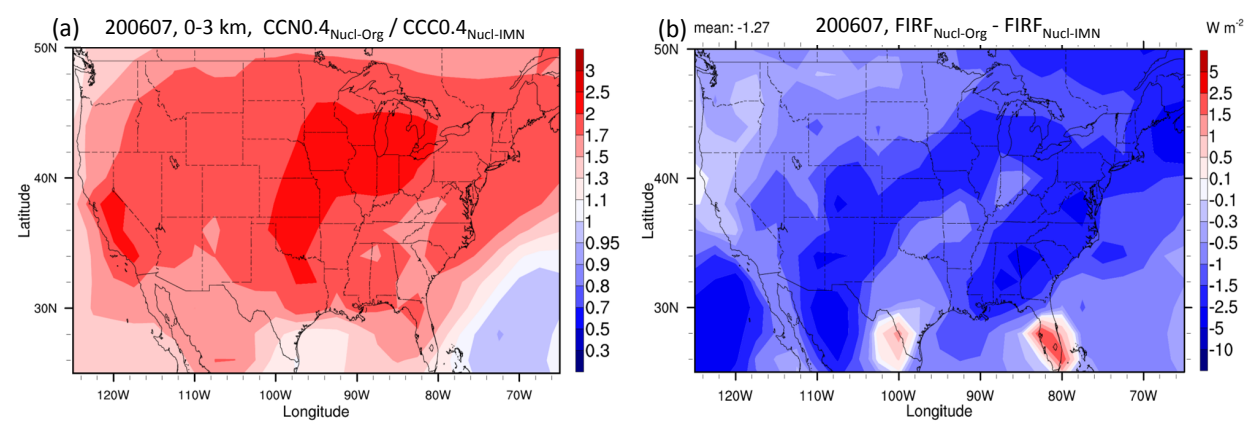

Figure 5. (a) Ratios of the concentration of CCN (at water supersaturation ratio of $0.4 \%$ ) in the lower troposphere (0-3 km) based on Nucl-Org scheme to those based on Nucl-IMN scheme, and (b) difference of aerosol first indirect radiative forcing (FIRF) (FIRF Nucl-Org $-^{-}$

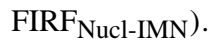

2 (DUK, MMSF) and 4-6 (EGB, WFM, PSP), while NuclIMN slightly underpredicts $F_{\text {nucl }}$ (by $\sim 10 \%$ ) for sites 2 and 3 (MMSF, SPL). On average, Nucl-Org overpredicts $F_{\text {nucl }}$ by $50 \%$ while $F_{\text {nucl }}$ based on Nucl-IMN (7\%) is close to the observed value ( $8 \%$ ) for the nine sites in the summer month.

$F_{\text {nucl }}$ alone is not adequate to assess the performance of the model. For example, for site 2 (MMSF) in March, $F_{\text {nucl }}$ based on Nucl-IMN is closer to the observed values than $F_{\text {nucl }}$ based on Nucl-Org, but $r$ and PC are actually lower (Fig. 4c). Our analysis indicates that a large fraction of NPF event days predicted by Nucl-IMN for MMSF in March do not match the NPF events observed on specific days. In terms of $r$ and PC, the values based on Nucl-Org and Nucl-IMN are close for the spring month (Fig. 4c and Table 2), but Nucl-IMN overall gives higher $r$ and PC values for July (Fig. 4d and Table 2). The correlation was calculated for a whole month of hourly $\mathrm{CN}_{10-100}$ data ( $\sim 700$ data points). Due to clear diurnal variations associated with NPF in the spring (Fig. 3a) and the fact that both schemes capture $\sim 70 \%$ of event and nonevent days, the average $r$ value reaches 0.37 for Nucl-Org and 0.49 for Nucl-IMN. As a result of the lack of obvious diurnal variations and inability of the global model to capture the sub-grid $\mathrm{CN}$ plumes (such as the short-duration $\mathrm{CN}$ spikes in Fig. 3h), the $r$ value is much lower for July (ninesite average of 0.16 for Nucl-Org and 0.22 for Nucl-IMN), although PC reaches 0.88 for Nucl-IMN. The lower average PC value for Nucl-Org (0.43) is due to the overprediction of NPF events (i.e., $\left.F_{\text {nucl }}\right)$.

Particle number concentrations and $\mathrm{CN}_{10-100}$ in NA (on a regional scale) are largely dominated by secondary particles formed via nucleation (Yu and Luo, 2009). Our analysis demonstrates that nucleation schemes have a strong impact on the simulated particle number concentrations. Compared to observations, $\mathrm{CN}_{10-100}$ averaged at the four sites is $40 \%$ higher based on Nucl-Org and $14 \%$ higher based on NuclIMN for the spring month (Table 2). For the summer month, $\mathrm{CN}_{10-100}$ averaged at the nine sites is $161 \%$ higher based on Nucl-Org and $27 \%$ lower based on Nucl-IMN (Table 2). For specific sites (Fig. $4 \mathrm{e}-\mathrm{f}$ ), $\mathrm{CN}_{10-100}$ based on Nucl-Org are generally higher than observed values in the spring for all four sites (especially site 1 - DUK) and are much higher than those in the summer month for sites 1 and 2 (DUK, MMSF) and 3-5 (SPL, EGB, WFM). Nucl-IMN substantially overpredicted $\mathrm{CN}_{10-100}$ for site 4 (EGB) in the spring and underpredicted $\mathrm{CN}_{10-100}$ for sites 8 and 9 (TNF, OZA) in the summer month. Possible sources of the difference include sub-grid inhomogeneity as well uncertainties in emissions, chemistry, aerosol microphysics, and meteorology. It is noteworthy that the global model, with a horizontal resolution of $2^{\circ} \times 2.5^{\circ}$, is aimed to capture regional events. If the measurements at a given site during certain periods were affected by sub-grid-scale topography and processes (emissions, plumes, etc.), the global model would not be able to capture these effects. Comparisons of high-resolution simulations with observations are needed to address the issue.

\section{Implications and discussion}

We showed in the last section that Nucl-Org and Nucl-IMN schemes predict quite different spatial distributions and significant differences between the spring and summer seasons with respect to NPF events. Table 2 shows that Nucl-IMN predictions agree better with observations in all categories, especially during July. One logical question to ask is, what is the implication of such differences? Figure 5 gives the ratios of the $\mathrm{CCN}$ concentration in the lower troposphere $(0$ $3 \mathrm{~km}$ ) based on Nucl-Org to the CCN concentration based on Nucl-IMN as well as the difference of aerosol FIRF $\left(\right.$ FIRF $_{\text {Nucl-Org }}-$ FIRF $\left._{\text {Nucl-IMN }}\right)$. The CCN concentrations are calculated at a water supersaturation ratio of $0.4 \%$ (CCN0.4) from simulated PSDs and the calculation of aerosol FIRF in GEOS-Chem is based on the approach discussed in Yu et al. (2013). As a result of higher nucleation rates, $\mathrm{CCN} 0.4 \mathrm{~s}$ based on Nucl-Org are approximately a factor of 2 higher than CCN0.4s based on Nucl-IMN in July over most parts of NA (Fig. 5a). Higher CCN leads to higher cloud droplet number concentrations and enhanced cloud albedo, resulting in an additional negative FIRF (cooling) of $1-2.5 \mathrm{~W} \mathrm{~m}^{-2}$ in a large 
fraction of NA, with a domain average of $-1.27 \mathrm{~W} \mathrm{~m}^{-2}$. Since CCN can also impact precipitation (second indirect impact) and cloud cover, it is important to reduce uncertainty in the new particle formation calculation in regional and global climate models.

The significant overprediction of NPF events and particle number concentrations in the summer by the Nucl-Org scheme cannot be explained by the uncertainty in the prefactor $\left(k_{m}\right)$ in the Nucl-Org parameterization (Eq. 1). It indicates that the organics-enhanced nucleation parameterization derived from laboratory chamber studies may not be directly applicable to the atmospheric conditions, at least in the summer months when VOC emissions, photochemistry, and SOA formation are strongest. One possible explanation for this result is that the concentration of organic compounds and their oxidation products exist at much lower concentrations in the atmosphere than those used in chamber studies. While both LV-SOG ${ }_{\alpha \text {-pinene }}$ in the model and BioOxOrg in the chamber studies are later-generation oxidation products of biogenic monoterpenes, it is possible that $\mathrm{LV}-\mathrm{SOG}_{\alpha-\text { pinene }}$ predicted in the model is not representative of $\mathrm{BioOxOrg}$ vapors that are involved in nucleation in the chamber studies. The uncertainty in the predicted concentrations of organic compounds actively participating in nucleation will impact not only the calculated nucleation rates but also the growth rate of these particles. Nevertheless, this will not be able to explain the observed spring-summer contrast in NPF since the concentrations of these specific compounds (i.e., BioOXOrg) are much higher in the summer, but observations show more frequent and stronger NPF events in the spring (Table 2 and Fig. 4).

Another possible reason for the overprediction of the Nucl-Org scheme is the influence of temperature. According to the Nucl-IMN scheme, the main reason for the lack of nucleation in July in relatively clean environments is the high temperature that reduces the supersaturation ratio of sulfuric acid and NPF. It should be noted that the Nucl-Org parameterization (Eq. 1) was derived from laboratory chamber studies at $T=278 \mathrm{~K}$ and $\mathrm{RH}=39 \%$ (Riccobono et al., 2014). Based on nucleation theory, temperature should influence the nucleation rate significantly unless the nucleation is barrierless. Higher summer temperatures may inhibit $\mathrm{H}_{2} \mathrm{SO}_{4}-$ organic nucleation and thus explain the lack of NPF in forest areas. If this is the case, the thermodynamic data for the $\mathrm{H}_{2} \mathrm{SO}_{4}$-organics system is needed to derive a $T$-dependent nucleation scheme, which is presently not available. Furthermore, water vapor and base molecules such as ammonia and amines may also affect nucleation barriers and thus nucleation rates. On the other hand, ammonia, amines, and certain organics concentrations are typically much higher in the summer and can also enhance IMN when the nucleation barrier is higher. This may explain the July underprediction of $\mathrm{CN}$ by binary IMN.

Further research is needed to understand the different mechanisms of NPF in the atmosphere in different environments and represent them properly in the models. Continuous field measurements of PSDs down to nanometer sizes (with improved accuracy in smaller sizes) in various environments along with concentrations of key precursor gasses are important. Thermodynamic data with regard to the interactions and stability of multiple-component pre-nucleation clusters are essential to develop more robust nucleation schemes that can take into account major influencing factors. Finally, developed nucleation schemes should be validated against field measurements taken under a wide range of varying conditions (such as season, temperature, vegetation types, and complexity of terrain).

\section{The Supplement related to this article is available online at doi:10.5194/acp-15-13993-2015-supplement.}

Acknowledgements. This study was supported by NASA under grants NNX13AK20G and NNX11AQ72G, and the US National Science Foundation (NSF). S. C. Pryor acknowledges financial support from NSF (no. 1517365). J. J. Schwab acknowledges funding from the US Department of Energy, contract DE-SC0011664. The National Center for Atmospheric Research is supported by the US National Science Foundation. The Steamboat Ski Resort provided logistical support and in-kind donations to Storm Peak Laboratory. The Desert Research Institute, which owns and operates Storm Peak Laboratory, is a permittee of the Medicine-Bow Routt National Forests and is an equal opportunity service provider and employer. Ian McCubbin provided technical assistance with the maintenance and data quality control for the aerosol instruments at SPL, and we are grateful. The GEOS-Chem model is managed by the Atmospheric Chemistry Modeling Group at Harvard University with support from NASA's Atmospheric Chemistry Modeling and Analysis Program.

Edited by: V.-M. Kerminen

\section{References}

Almeida, J., Schobesberger, S., Kurten, A., Ortega, I. K., Kupiainen-Maatta, O., Praplan, A. P., Adamov, A., Amorim, A., Bianchi, F., Breitenlechner, M., David, A., Dommen, J., Donahue, N. M., Downard, A., Dunne, E., Duplissy, J., Ehrhart, S., Flagan, R. C., Franchin, A., Guida, R., Hakala, J., Hansel, A., Neinritzi, M., Henschel, H., Jokinen, T., Kajos, M., Kangasluoma, J., Keskinen, H., Kupc, A., Kurtén, T., Kvashin, A. N., Laaksonen, A., Lehtipalo, K., Leiminger, M., Leppä, J., Loukonen, V., Makhmutov, V., Mathot, S., McGrath, M. J., Nieminen, T., Olenius, T., Onnela, A., Petäjä, T., Riccobono, F., Riipinen, I., Rissanen, M., Rondo, L., Ruuskanen, T., Santos, F.D., Sarnela, N., Schallhart, S., Schnitzhofer, R., Seinfeld, J. H., Simon, M., Sipilä, M., Stozhkov, Y., Stratmann, F., Tomé, A., Tröstl, J., Tsagkogeorgas, G., Vaattovaara, P., Viisanen, Y., Virtanen, A., Vrtala, A., Wagner, P. E., Weingartner, E., Wex, H., Williamson, C., Wimmer, D., Ye, P., Yli-Juuti, T., Carslaw, K. S., Kulmala, 
M., Curtius, J., Baltensperger, U., Worsnop, D. R., Vehkamäki, H., and Kirby, J., Molecular understanding of sulphuric acidamine particle nucleation in the atmosphere, Nature, 502, 359363, 2013.

Bae, M.-S., Schwab, J. J., Hogrefe, O., Frank, B. P., Lala, G. G., and Demerjian, K. L.: Characteristics of size distributions at urban and rural locations in New York, Atmos. Chem. Phys., 10, 45214535, doi:10.5194/acp-10-4521-2010, 2010.

Berndt, T., Sipilä, M., Stratmann, F., Petäjä, T., Vanhanen, J., Mikkilä, J., Patokoski, J., Taipale, R., Mauldin III, R. L., and Kulmala, M.: Enhancement of atmospheric $\mathrm{H}_{2} \mathrm{SO}_{4} / \mathrm{H}_{2} \mathrm{O}$ nucleation: organic oxidation products versus amines, Atmos. Chem. Phys., 14, 751-764, doi:10.5194/acp-14-751-2014, 2014.

Bey, I., Jacob, D. J., Yantosca, R. M., Logan, J. A., Field, B., Fiore, A. M., Li, Q., Liu, H., Mickley, L. J., and Schultz, M., Global modeling of tropospheric chemistry with assimilated meteorology: Model description and evaluation, J. Geophys. Res., 106, 23073-23096, 2001.

Carslaw, K. S., Lee, L. A., Reddington, C. L., Pringle, K. J., Rap, A. Forster, P. M., Mann, G. W., Spracklen, D. V., Woodhouse, M. T., Regayre, L. A., and Pierce, J. R.: Large contribution of natural aerosols to uncertainty in indirect forcing, Nature, 503, 67-71, doi:10.1038/nature12674, 2013.

Chen, M., Titcombe, M., Jiang, J., Kuang, Fischer, M. L., Edgerton, E., Eisele, F. L., Siepmann, J. I., Hanson, D. H., Zhao, J., and McMurry, P. H.: Acid-base chemical reaction model for nucleation rates in the polluted boundary layer, Proc. Natl. Aca. Sci., 109, 18713-18718, 2012.

Chung, S. H. and Seinfeld, J. H.: Global distribution and climate forcing of carbonaceous aerosols, J. Geophys. Res., 107, 4407, doi:10.1029/2001JD001397, 2002.

Dal Maso, M., Kulmala, M., Dal Maso, M., Riipinen, I.,Wagner, R., Hussein, T., Aalto, P., and Lehtinen, K. E. J.: Formation and growth of fresh atmospheric aerosols: eight years of aerosol size distribution data from SMEAR II, Hyytiala, Finland, Boreal Environ. Res., 10, 323-336, 2005.

Dawson, M. L., Varner, M. E., Perraud, V., Ezell, M. J., Gerber, R. B., and Finlayson-Pitts, B. J.: Simplified mechanism for new particle formation from methanesulfonic acid, amines, and water via experiments and ab initio calculations, Proc. Natl. Aca. Sci., 109, 18719-18724, 2012.

Ehn, M., Thornton, J., Kleist, E., Sipilä, M., Junninen, H., Pullinen, I., Springer, M., Rubach, F., Tillmann, R., Lee, B., LopezHilfiker, F., Andres, S., Acir, I.-H., Rissanen, M., Jokinen, T., Schobesberger, S., Kangasluoma, J., Kontkanen, J., Nieminen, T., Kurtén, T., Nielsen, L., Jørgensen, S., Kjaergaard, H., Canagaratna, M., Maso, M., Berndt, T., Petäjä, T., Wahner, A., Kerminen, V.-M., Kulmala, M., Worsnop, D., Wildt, J., and Mentel, T.: A large source of low-volatility secondary organic aerosol, Nature, 506, 476-479, doi:10.1038/nature13032, 2014.

Erupe, M. E., Viggiano, A. A., and Lee, S.-H.: The effect of trimethylamine on atmospheric nucleation involving $\mathrm{H}_{2} \mathrm{SO}_{4}$, Atmos. Chem. Phys., 11, 4767-4775, doi:10.5194/acp-11-47672011, 2011.

Evans, M. J. and Jacob, D. J.: Impact of new laboratory studies of $\mathrm{N}_{2} \mathrm{O}_{5}$ hydrolysis on global model budgets of tropospheric nitrogen oxides, ozone, and OH, Geophys. Res. Lett., 32, L09813, doi:10.1029/2005GL022469, 2005.
Glasoe, W. A., Volz, K., Panta, B., Freshour, N., Bachman, R., Hanson, D. R., McMurry, P. H., and Jen, C.: Sulfuric acid nucleation: An experimental study of the effect of seven bases, J. Geophys. Res.-Atmos., 120, doi:10.1002/2014JD022730, 2015.

Guenther, A., Karl, T., Harley, P., Wiedinmyer, C., Palmer, P. I., and Geron, C.: Estimates of global terrestrial isoprene emissions using MEGAN (Model of Emissions of Gases and Aerosols from Nature), Atmos. Chem. Phys., 6, 3181-3210, doi:10.5194/acp-63181-2006, 2006.

Hallar, A. G., Lowenthal, D. H., Chirokova, G., Wiedinmyer, C., and Borys, R. D.: Persistent daily new particle formation at a mountain-top location, Atmos. Environ., 45, 4111-4115, doi:10.1016/j.atmosenv.2011.04.044, 2011.

Henze, D. K., Seinfeld, J. H., Ng, N. L., Kroll, J. H., Fu, T.-M., Jacob, D. J., and Heald, C. L.: Global modeling of secondary organic aerosol formation from aromatic hydrocarbons: highvs. low-yield pathways, Atmos. Chem. Phys., 8, 2405-2420, doi:10.5194/acp-8-2405-2008, 2008.

IPCC (Intergovernmental Panel on Climate Change): The Physical Science Basis, Working Group I Contribution to the IPCC 5th Assessment Report - Changes to the Underlying Scientific/Technical Assessment, Cambridge Univ. Press, New York, 2013.

Kanawade, V. P., Jobson, B. T., Guenther, A. B., Erupe, M. E., Pressley, S. N., Tripathi, S. N., and Lee, S.-H.: Isoprene suppression of new particle formation in a mixed deciduous forest, Atmos. Chem. Phys., 11, 6013-6027, doi:10.5194/acp-11-60132011, 2011.

Kazil, J., Stier, P., Zhang, K., Quaas, J., Kinne, S., O’Donnell, D., Rast, S., Esch, M., Ferrachat, S., Lohmann, U., and Feichter, J.: Aerosol nucleation and its role for clouds and Earth's radiative forcing in the aerosol-climate model ECHAM5-HAM, Atmos. Chem. Phys., 10, 10733-10752, doi:10.5194/acp-1010733-2010, 2010.

Knibbs, L. D., Cole-Hunter, T., and Morawska, L.: A review of commuter exposure to ultrafine particles and its health effects, Atmos. Environ., 45, 2611-2622, 2011.

Kulmala, M., Vehkamaki, H., Petäjä , T., Dal Maso, M., Lauri, A., Kerminen, V.-M., Birmili, W., and McMurry, P.: Formation and growth rates of ultrafine atmospheric particles: A review of observations, J. Aerosol Sci., 35, 143-176, 2004.

Lee, S. H., et al:, New insights on isoprene suppression of biogenic new particle formation, in preparation, 2015.

Lehtinen, K. E. J. and Kulmala, M.: A model for particle formation and growth in the atmosphere with molecular resolution in size, Atmos. Chem. Phys., 3, 251-257, doi:10.5194/acp-3-251-2003, 2003.

Liao, H., Henze, D. K., Seinfeld, J. H., Wu, S., and Mickley, L. J.: Biogenic secondary organic aerosol over the United States: Comparison of climatological simulations with observations, J. Geophys. Res., 112, D06201, doi:10.1029/2006JD007813, 2007.

Martin, R. V., Jacob, D. J., Yantosca, R. M., Chin, M., and Ginoux, P.: Global and regional decreases in tropospheric oxidants from photochemical effects of aerosols, J. Geophys. Res., 108, 4097, doi:10.1029/2002JD002622, 2003.

Park, R. J., Jacob, D. J., Field, B. D., Yantosca, R. M., and Chin, M.: Natural and transboundary pollution influences on sulfate-nitrate-ammonium aerosols in the United 
States: Implications for policy, J. Geophys. Res., 109, D15204, doi:10.1029/2003JD004473, 2004.

Pierce, J. R. and Adams, P. J.: Uncertainty in global CCN concentrations from uncertain aerosol nucleation and primary emission rates, Atmos. Chem. Phys., 9, 1339-1356, doi:10.5194/acp-91339-2009, 2009.

Pierce, J. R., Westervelt, D. M., Atwood, S. A., Barnes, E. A., and Leaitch, W. R.: New-particle formation, growth and climaterelevant particle production in Egbert, Canada: analysis from 1 year of size-distribution observations, Atmos. Chem. Phys., 14, 8647-8663, doi:10.5194/acp-14-8647-2014, 2014.

Pillai, P., Khlystov, A., Walker, J., and Aneja, V.: Observation and analysis of particle nucleation at a forest site in southeastern US, Atmosphere, 4, 72-93, 2013.

Pryor, S. C., Spaulding, A. M., and Barthelmie, R. J.: New particle formation in the Midwestern USA: Event characteristics, meteorological context and vertical profiles, Atmos. Environ., 44, 4413-4425, 2010.

Pryor, S. C., Hornsby, K. E., and Novick, K. A.: Forest canopy interactions with nucleation mode particles, Atmos. Chem. Phys., 14, 11985-11996, doi:10.5194/acp-14-11985-2014, 2014.

Riccobono, F., Schoberberger, S., Scott, C. E., Dommen, J., Ortega, I. K., Rondo, L., Almeida, J., Amorim, A., Bianchi, F., Breitenlechner, M., David, A., Downard, A., Dunne, E. M., Duplissy, J., Ehrhardt, S., Flagan, R. C., Franchin, A., Hansel, A., Juuninen, H., Kajos, M., Keskinen, H., Kupc, A., Kürten, A., Kvashin, A. N., Laaksonen, A., Lehtipalo, K., Makkmutov, V., Mathot, S., Nieminen, T., Onnela, A., Petäjä, T., Praplan, A. P., Santos, F. D., Schallhart, S., Seinfeld, J. H., Sipilä, M., Spracklen, D. V., Stozhkov, Y., Stratmann, F., Tomé, A., Tsagkogeorgas, G., Vaattlovaara, P., Viisanen, Y., Vrtala, A., Wagner, P. E., Weingartner, E., Wex, H., Wimmer, D., Carslaw, K. S., Curtius, J., Donahue, N. M., Kirkby, J., Kulmala, M. Worsnop, D. R., and Baltensperger, U.: Oxidation products of biogenic emissions contribute to nucleation of atmospheric particles, Science, 344, p. 717, doi:10.1126/science.1243527, 2014.

Slowik, J. G., Stroud, C., Bottenheim, J. W., Brickell, P. C., Chang, R. Y.-W., Liggio, J., Makar, P. A., Martin, R. V., Moran, M. D., Shantz, N. C., Sjostedt, S. J., van Donkelaar, A., Vlasenko, A., Wiebe, H. A., Xia, A. G., Zhang, J., Leaitch, W. R., and Abbatt, J. P. D.: Characterization of a large biogenic secondary organic aerosol event from eastern Canadian forests, Atmos. Chem. Phys., 10, 2825-2845, doi:10.5194/acp-10-2825-2010, 2010.

Spracklen, D. V., Carslaw, K. S., Kulmala, M., Kerminen, V.M.,Sihto, Riipinen, I., Merikanto, J., Mann, G. W., Chipperfield, M. P., Wiedensohler, A., Birmili, W., and Lihavainen, H.: Contribution of particle formation to global cloud condensation nuclei concentrations, Geophys. Res. Lett., 35, L06808, doi:10.1029/2007GL033038, 2008.
Venzac, H., Sellegri, K., Laj, P., Villani, P., Bonasoni, P., Marinoni, A., Cristofanelli, P., Calzolari, F., Fuzzi, S., Decesari, S., Facchini, M.-C., Vuillermoz, E., and Verza, G. P.: High frequency new particle formation in the Himalayas, Proc. Natl. Aca. Sci. USA, 105, 15666-15671, 2008.

Wang, M. and Penner, J. E.: Aerosol indirect forcing in a global model with particle nucleation, Atmos. Chem. Phys., 9, 239-260, doi:10.5194/acp-9-239-2009, 2009.

$\mathrm{Yu}, \mathrm{F}$.: Ion-mediated nucleation in the atmosphere: Key controlling parameters, implications, and look-up table, J. Geophys. Res., 115, D03206, doi:10.1029/2009JD012630, 2010.

Yu, F.: A secondary organic aerosol formation model considering successive oxidation aging and kinetic condensation of organic compounds: global scale implications, Atmos. Chem. Phys., 11, 1083-1099, doi:10.5194/acp-11-1083-2011, 2011.

Yu, F. and Hallar, G.: Difference in particle formation at a mountaintop location during the spring and summer: Implications for the role of sulfuric acid and organics in nucleation, J. Geophys. Res., 119, 12246-12255, doi:10.1002/2014JD022136, 2014.

Yu, F. and Luo, G.: Simulation of particle size distribution with a global aerosol model: contribution of nucleation to aerosol and CCN number concentrations, Atmos. Chem. Phys., 9, 76917710, doi:10.5194/acp-9-7691-2009, 2009.

Yu, F., Luo, G., Liu, X., Easter, R. C., Ma, X., and Ghan, S. J.: Indirect radiative forcing by ion-mediated nucleation of aerosol, Atmos. Chem. Phys., 12, 11451-11463, doi:10.5194/acp-1211451-2012, 2012.

Yu, F., Ma, X., and Luo, G.: Anthropogenic contribution to cloud condensation nuclei and the first aerosol indirect climate effect, Environ. Res. Lett., 8, 024029, doi:10.1088/17489326/8/2/024029, 2013.

Yu, H., Ortega, J., Smith, J. N., Guenther, A. B., Kanawade, V. P., You, Y., Liu, Y., Hosman, K., Karl, T., Seco, R., Geron, C., Pallardy, S. G., Gu, L., Mikkilä, J., and Lee, S. H.: New particle formation and growth in an isoprene-dominated Ozark forest: From sub-5 nm to CCN-active sizes, Aerosol Sci. Technol., 48, 12851298, 2014.

Zhang, R., Suh, I., Zhao, J., Zhang, D., Fortner, E. C., Tie, X., Molina, L. T., and Molina, M. J.: Atmospheric new particle formation enhanced by organic acids, Science, 304, 1487-1490, 2004. 